\title{
Leadership Effect on the Retention of Nongovernmental Organizations (NGOs) Employees in Thailand
}

\author{
*Matchakarn Ya-Anan, Chanchai Bunchapattanasukda \\ Shinawatra University, Bangkok, Thailand \\ *matchakarn_mot@hotmail.com
}

\begin{abstract}
This study examines the affect of leadership on the retention of employees in NGOs. Four Thai NGOs representing a variety of organizational types were selected as a case study: the Paveenahongsakul Foundation, the Duang Prateep Foundation, the Potektueng Foundation, and the Chaipattana Foundation. They all work largely in the field of social and community development, with specific interests varying from: literacy, education, health, child and women welfare, environment, advocacy, animal welfare, volunteer promotion, etc. All of these NGOs are large enough to require skilled employees and an executive staff that is concerned about retaining these employees. This research aims to understand and critique the success factors for employee retention and examine if these factors hold true against the broad diversity of NGOs. In particular this study focuses on how leadership, which maintains the mission and vision of the NGO, impacts employee retention and what effect employee changeover has on maintaining mission and vision.
\end{abstract}

Key words: Nongovernmental organization, leadership, employee retention.

\section{Introduction}

Non-Governmental Organizations (NGOs) have increasingly come to play a significant role in providing essential services for the development of society (Davids et. al, 2009). NGOs' work can span national boundaries, especially those NGOs responsible for active efforts in international development and improving the welfare of poor in developing countries. Just as we require strong oversight for governmental projects, we require the same for nongovernmental organizations that take on these roles. This increased professionalism requires that NGOs employ highly trained staff and they are competing in the same labor market as private enterprise for these staff. NGOs are often seen as being at a disadvantage with private enterprise in providing monetary compensation and instead rely on using their Mission to attract like minded employees. Leadership is important within any enterprise for managing staff and the setting of priorities, but within NGOs, leadership is also responsible for articulating the vision of the organization. This study examines the effect leadership has on the retention of employees that work for NGOs in Thailand.

The objectives of this study are to find and explain leadership's effect on the retention of employees working for NGOs, and to highlight the leader's perspective on employee retention.

\section{Literature Review}

Nongovernment Organizations (NGOs): Andriof et al., (2002), Goodstein and Wicks, (2007) point out that NGOs have gradually strengthened their influence in society and that this societal evolution can best be seen by the changed external environment that private enterprise must now work under. Civil society now expects business to take its responsibilities on an increasing number of issues seriously. Stakeholder theory strongly urges an ethical approach, based on respect and consideration of a firm's constituencies. Ruggie (2004) argues that NGOs also engage corporations and business associations to identify and disseminate corporate best practices and to promote social and environmental actions, provide technical assistance to corporations, elaborate commonly agreed certification schemes, promote and design corporate social responsibility (CSR) standards as well as management and reporting processes, and participate in CSR monitoring and auditing. These new forms of collaboration between business and NGOs reflect broader changes in the overall governance environment, while contributing to the reconstitution of the global public domain where firms carry out their activity. As major donors, private enterprise can also set NGOs financial and other organizational imperatives (Sogge et al, 1996). 
Leadership: The increased professionalism as well as the competition for qualified employees can be seen by assessing where the graduates of Harvard University's Kennedy School of Government gain employment upon graduation. In 1980, 8 percent of the Masters in Public Policy graduates took jobs in the NGO sector (Kennedy School of Government, 1998). By 2004, that number had risen to over 31 percent (Kennedy School of Government, 2004). In 2007, Canada had more than 72,000 registered charities delivering services locally, provincially and nationally. These organizations provide over 350,000 full time jobs as well as over 220,000 part time jobs. Total annual salaries exceed $\$ 13$ billion dollars. This is a large and growing sector (Hardy, 2007). NGOs are better managed than they once were, and one aspect of that improved management is having a growing and more secure revenue source. Hence, when defined as a process of influence, leadership is broader than management. Influence can come from stakeholders inside and outside the firm (Frooman, 1999). Schermerhorn (2006) pointed out that leadership is the process of inspiring others to work hard to accomplish important tasks with the rapid technological change, intense global competition, and workforce diversity of the new workplace leadership is essential to management. Planning sets the direction and objectives, organizing brings resources together to turn plans into action, leading builds the commitment and enthusiasm needed for people to apply their talents fully to help accomplish plans and controlling makes sure things turn out right. The foundation of effective leadership lies in the ways a manager uses power to influence the behavior of other people. Power is the ability to get someone else to do something you want done. It is this ability to make things happen the way you want them to (Moss, 1997). Power is essential to executive success. To be successful at leadership, a leader must be able to both acquire and appropriately use positional power and personal power (Whetten and Cameron, 1991).

Leadership in NGOs is not that different from that of the for-profit sector (Hardy, 2007). Though NGOs may have a social purpose, such as environmental or human rights, their clients (beneficiaries) are different from the people who contribute time and resources; as such they are also called nonmembership organizations (Ebrahim, 2003). Many NGO's have had to evolve or die as they compete for limited resources and make themselves relevant to a changing cliental, and Boards of Directors are forced to accept the notion that not every agency could be expected to survive. As such, NGO's began to look at the world through a filter that was well known in the for-profit sector (Hardy, 2007). Providing job satisfaction and leader acceptance, leader behaviour must be perceived as immediately satisfying or as leading to future satisfaction. Leader behavior that employees see as unnecessary or unhelpful, will be resented (House and Desslers, 1974).

Retention: Organizations are struggling with turnover and retention but are taking steps to deal with it as The Institute of Management and Administration (2008) found these solutions fall into four categories:

- making sure compensation is up to market levels,

- having regular check-ins with existing employees to be sure they are satisfied,

- creating succession plans,

- ensuring new hires are a good fit for the organization.

According to Brundage and Koziel (2010), the initial step in achieving retention success is instilling in the firm a culture that people are the top priority. This must come from the top of the leadership hierarchy and flow down through the organization. Building a cohesive staffing system should be based on a common foundation, such as a competency model, that applies to all levels within the firm. For example, a competency model helps managers to counsel poor performers because it displays the behaviors and actions that team members should be demonstrating. This will demonstrate a commitment to the people power of the organization and will regularly promote retention efforts. When retention becomes a priority, that mindset flows through the firm and staffing programs will naturally gravitate toward maximizing employee satisfaction and retaining the best and brightest talent. There are many possible ways to creatively link reward and performance in the new workplace. To take full advantage of the possibilities, however, managers must:

- respect diversity and individual differences,

- clearly understand what people want from work

- allocate rewards to satisfy the interests of both individuals and the organization (Schermerhorn, 2006).

\section{Conceptual Framework}

The conceptual framework for this study was that employees would be attracted to work for these NGOs based upon the vision and mission of the organizations. This vision and mission is articulated by the 
leadership. Retaining these employees is dependent upon how the vision and mission is articulated by the leadership in its daily interactions with employees.

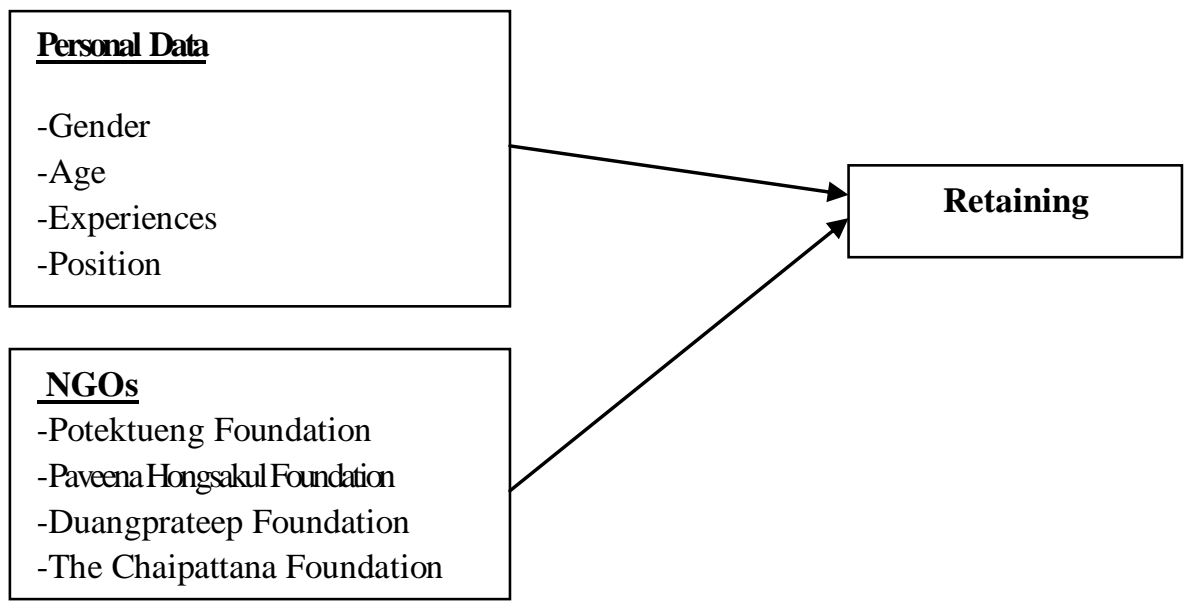

\section{Methodology}

The author approached four Bangkok based NGOs of good reputation and of sufficient size to warrant a human resource management plan. These four NGOs were: The Paveenahongsakul Foundation primarily a child and women's social welfare and rights promotion organization; The Duang Prateep Foundation began its work on promoting the welfare of inhabitants of the Klong Toey slum in Bangkok and now works in a number of slum communities; The Potektueng Foundation deals with health, accidents and natural disasters; and The Chaipattana Foundation which provides support for royally initiated projects. In-depth interviews were held at the convenience of the interviewees.

\section{Results and Analysis}

It is clear from the interviews, that employees are selected for their motivation in being part of the mission and vision of the organization. Leadership looked to hire people with like motivations. For example the Paveenahongsakul Foundation only hired women that loved children, while the Chaipattana Foundation was looking for employees that sought to work on behalf of the crown.

Some organizations put greater emphasis on employees as members of the family, hoping that strong social interactions would strengthen commitment and retention. The Potektueng Foundation deemphasized leadership interactions and instead encouraged social networking amongst its employees and volunteers and devotion to its cause. The leadership of the Duang Prateep Foundation often seeks to encourage employee interaction and sees this as part of their mission as many employees come from their target community.

Organizations are faced with financial limitations and look to other methods of rewarding employees. Some of these are in additional benefits such as vacation, sick leave, and medical insurance. Some organizations use training and job rotations to reward good employees. Management is concerned about employee retention. Most of those interviewed said that they conducted some form of exit interview to discover why employees were leaving and what could be done to retain future employees.

\section{Conclusion}

According to Schermerhorn (2006) the leader builds the commitment and enthusiasm so that people apply their talents fully to help accomplish plans and monitoring makes sure things turn out right. A leader must be good at dealing with all aspects of communication, interpersonal relations and motivation.

This study has shown that leadership affects the retention of employees working for nongovernmental organizations (NGOs) in Thailand. Leadership directly affects the retention of employees as the leader is responsible for job descriptions, recruitment, and selection. More importantly, the leader's ability to communicate the organization's vision and mission impact the motivation of employees. Finally the greater the experience or professionalism of the leader the better they are at managing and retraining staff. Employees differ in many ways including their capabilities, attitudes, personal goals and 
personalities. Therefore, behavior that the leader finds effective with one worker may not be effective with another. In extreme cases, employees can be so different that it was virtually impossible for them to be managed as a group. In order to be effective, the leader must consider both individual and group differences.

The leader must learn that there are two organizations, one formal and the other informal. An organization is usually described by an organizational chart, job descriptions and rewards. Leaders know the official reporting relationships. But an informal organization exists alongside, especially for those organizations that try to foster team or social group building or rely on their target cliental to supply labor. While key factors surrounding leadership where elicited using in-depth interviews, the study also identified other factors affecting employee retention, including geographic area, quality of life, desire for further professional development and a more flexible work schedule.

According to Hardy (2007), in the NGO world it is important that one leads with heart as well as head. Employees often come to an organization based on its mission and vision, and it is up to the leader to constantly articulate this in their daily interactions with employees and volunteers. This may require new skills including: vision and strategic planning, a desire to innovate, a willingness to take considered risks, the ability to create and sustain growth, the ability to delegate and collaborate, excellent communication skills, and risk management and crisis intervention skills.

Acknowledgement: I wish to thank Shinawatra International University which granted me the opportunity and scholarship to pursue my study for a Degree of Doctor of Philosophy in Management Science and I wish to express my deepest gratitude to my advisor, Asst Prof. Dr. Chanchai Bunchapattanasakda, for all his support, guidance, insights and patience in helping me. I would like to express my heartfelt gratitude to all the interviewees working for foundations in Thailand. I appreciated their support, kind interaction and generosity in sharing information and opinions for this special study. The data collection would never have succeeded without their cooperation.

\section{References}

Andriof, J., Waddock, S., Husted, B. S. \& Rahman, S. (2002). Unfolding Stakeholder Thinking: Greenleaf Publishing, Sheffield.

Brundage, H., \& Koziel, M. (2010). Retaining top talent still a requirement for firms: focus on people now to keep turnover costs down when the economy improves. Journal of Accountancy, 209 (5), 3844.

Davids, I., Theron, F., \& Maphunye K. J. (2009). Participatory Development in South Africa. A Development Management in South Africa. A Development Management Perspective. (2nd ed.). Van Schaik Publishers, Pretoria.

Ebrahim, A. (2003). NGOs and Organizational Change: Discourse, Reporting and Learning. U.K.: Cambridge University Press.

Frooman, J. (1999). Stakeholder Influence Strategies. The Academy of Management Review 24(2), 191205.

Goodstein, J. \& Wicks, A. (2007).Corporate and Stakeholder Responsibility. Making Business Ethics a TwoWay Conversation. Business Ethics Quarterly 17, 375-398.

Hardy, B. (2007).Leadership in NGO's: is it all that different than the for-profit sector. Gale, Cengage Learning.

House, R. J. \& Dessler, G. (1974). The path-goal theory of leadership: Some post hoc and a priori tests', in JG Hunt \& LL Larson (eds.), Contingency approaches to leadership, Southern Illinois University Press, Carbondale.

Schermerhorn, R. J. (2006). Management (6th ed): Printed in The United States of America.

Kennedy School of Government. (1998).Placement Report: 1998. Unpublished report. Harvard University.

Moss, K. R. (1997). Power Failure in Management Circuits. Harvard Business Review, 47, 65-75.

Ruggie, J. (2004). Reconstituting the Global Public Domain-Issues, Actors, and Practices', European Journal of International Relations 10(4), 499-531.

Sogge, D., Biekart, K. \& Saxby, J. (1996). Compassion \& Calculation: The Business of Private Foreign Aid. Pluto: London.

Sridhar M. K. and Manasa, N. (2008). NGOs in India- Uniqueness and Critical Success Factors, Results of an FGD. The Journal of Business Perspective, 12, 45-51.

Whetten, A. D. \& Cameron, K. S. (1991). Developing management skills. $2^{\text {nd }}$ ed .New York: HarperCollins 